\title{
CORRESPONDENCE
}

\section{MALVERN STRUCTURES}

SiR,-A few weeks ago, I had the opportunity to examine the new and increasingly extensive excavations at the Gullet Quarry in the southern part of the Malvern Hills, which last year prompted Dr. H. G. Reading and Mr. A. B. Poole (1961) to describe the junction of the Malvernian and Llandoverian rocks there, as a depositional one. I am inclined to question their interpretation of the nature of this junction, since the evidence now available includes many features indicative of faulting.

The eastern boundary of the new Gullet working coincides approximately with the plane of junction separating Llandoverian strata to the west from Malvernian rocks to the east; and, although the section of the junction photographed by Reading and Poole (ibid., pl. 15) does not seem to be well exposed now, I was able to examine the junction at a number of places further north, where the following conditions obtained:-

Exposure ( $I$ ) The Malvernian surface is vertical and polished, and faint vertical slickensiding is visible on the Llandoverian immediately adjacent to it. The Malvernian seems to transgress rapidly across the bedding planes of the Llandoverian strata, in the manner illustrated by Groom $(1899$, fig. 11) at another Silurian-Malvernian contact near the Hollybush Quarry. The Llandoverian rocks nearest to the Malvernian consist of greenish-fawn shales exhibiting signs of incipient shear, and external to them, a few inches away from the Malvernian, is a thin band of black, sheared shale.

Exposure (2) The Malvernian surface is again polished and vertical, but undulating, with the Llandoverian wrapped around the undulations. At the contact, the Silurian is represented by a somewhat sheared shale containing lenticles and fragments of a dark, greenish-grey, compact, flaggy siltstone. Six inches outwards from the Malvernian is a reddish, ferruginous clay packed with remains of pentamerids and other shelly fossils.

Exposure (3) The slickensided zone of junction dips eastwards at about $45^{\circ}$, and the Llandoverian stratification near the junction follows it, but gradually assumes a vertical disposition, downwards and outwards from the contact. Twenty yards to the west, at much the same topographical level, the Upper Llandoverian is represented by grey-green flaggy siltstones with some shaly bands, dipping westwards at about $45^{\circ}$.

Exposure (4) The Malvernian surface dips eastwards at $40^{\circ}$, with stratification in the adjacent Llandoverian disposed as it is at Exposure (3). At the junction, there is a thin layer of black, sheared shale. Immediately west of that is a mottled red and grey flaggy bed containing Llandoverian fossils, in turn succeeded by light coloured shales tending to be mildly sheared, so that they fragment into phacoidally shaped blocks. During field mapping in the South Malverns over a period of many years, $I$ have seen a fossiliferous horizon, similar to that noted above (3) high in the little disturbed UpperLlandoverian sequence forming the Obelisk escarpment, but I have never located anything similar in the lower part of that succession.

Exposure (5) The Malvernian face dips at about $45^{\circ}$ to the east. The "basal" bed of the Llandoverian, in an outcrop not more than a few feet across, consists of a plastic, grey-blue clay containing numerous wellrounded, haematite-coated pebbles and cobbles up to one foot in maximum diameter. No fossils were found in this bed. The next member of the Llandoverian, outwards from the Malvernian, consists of silts and shales, also dipping eastwards beneath the Pre-Cambrian at about $50^{\circ}$.

Exposure (6) The western surface of the Malvernian dips eastwards at about $45^{\circ}$, and is underlain by eastward-dipping Llandoverian shales. This exposure is only ten feet away from Exposure (5), but no conglomeratic horizon crops out at or near the Silurian-Pre-Cambrian contact.

Exposure (7) At the extreme north-eastern corner of the new GulletQuarry excavation, only fawn coloured Llandoverian shales, with lenses up 
to three inches thick of compact grey-green siltstones, are exposed; but clearly the Silurian-Malvernian junction lies buried only a few feet to the east of the excavation. At the western end of Exposure (7), the Llandoverian shales are standing vertically above, and downwards become inclined steeply to the west. At the eastern margin of the exposure, similarly dipping shales become overturned above, so that there they dip eastwards at $45^{\circ}$, and lie discordantly across the top of vertically disposed shales which are stratigraphically slightly higher in the Llandoverian sequence. To accomplish this, the eastward-dipping shales have been thrust, to a minor degree, over the top of adjacent higher beds.

The junction, therefore, between Upper Llandoverian strata and the Malvernian, now exposed at the Gullet Quarry, is more likely to be a faulted junction than a depositional one for the following reasons:--

(a) The plane of junction at outcrop is vertical, or more often overturned, and slickensiding is developed in the immediate vicinity of the junction.

(b) Close to the Malvernian surface, the Llandoverian shales show signs of shear.

(c) The adjacent Malvernian, immediately to the east of the junction in the main working, is traversed by numerous thr: sts and shear zones, often inclined, as Blyth (1952, p. 192) has already remarked, in the same direction as the junction.

(d) The Llandoverian near the Malvernian is vertical or locally overturned (in a manner which cannot be explained solely by surface creep), but quickly resumes a moderate westward dip twenty yards to the west. Moreover, at one small exposure, very near the junction, a tiny eastward-hading thrust is developed in the Llandoverian.

(e) The conglomeratic horizon, which Reading and Poole (ibid., p. 295) regard as the basal conglomerate of the Upper Llandoverian at its depositional union with the Malvernian, occurs only very sporadically along the outcrop of the junction.

The simplest explanation of all these features in combination would seem to be that at the Gullet the plane of contact is a fracture which undulates and does not conform precisely to the strike of the Silurian sediments. Thus, the conglomeratic horizon only crops out occasionally and rather fortuitously in the new Gullet excavations; and dips in the Llandoverian strata are dragged against the fault, and even overturned. Whether this conglomerate really is the local basal member of the Silurian is controversial, since Phillips (1848, p. 58) stated that conglomeratic horizons recur in the lower 600 feet of the Upper Llandoverian adjacent to the west side of the Malverns. It is well to remember, too, that the identifiable fossils collected by Reading and Poole (ibid., p. 295) at this Gullet Quarry junction are probably diagnostic of a very late Llandoverian zone-moment. Their occurrence at the local base of an Upper Llandoverian sequence would require very pronounced overlap, seemingly in a very short distance laterally.

From the conclusion that the Silurian-Pre-Cambrian junction at the Gullet is probably a faulted one, it is natural to turn briefly to a more general review of the nature of the western margin of the Malvern range which, according to Groom, is defined by a continuous and important system of faults. That view is, broadly speaking, accepted and reaffirmed by Raw (1951) and by Blyth (1952); and a similar assumption is perhaps implicit in Falcon (1947). In the opinion of Reading and Poole (1961, p. 299), however, faulting at the western boundary of the Malverns is neither continuous, nor of major kind.

In considering these conflicting views, certain relevant aspects of the relationship between the Silurian and the Malvernian seem to be indisputable. Firstly, along the entire western margin of the Malvernian rocks, Lower Palaeozoic strata, which a few hundred yards to the west are gently flexured into open (and often symmetrical) folds, become steepened, vertical, or are overturned with great regularity adjacent to the Pre-Cambrian. Secondly, wherever a segment of the Malvernian is situated appreciably to the west of 
the principal Malvern axis, there, the disturbance in the neighbouring Lower Palaeozoic rocks is correspondingly emphasized, with pronounced overturning, and sometimes squeezing out of argillaceous formations. This is particularly marked opposite the Herefordshire Beacon, but also occurs near Chase End Hill. Thirdly, in the past at various places along the western side of the Malverns, excellent exposures of a number of contacts between Lower Palaeozoic and Pre-Cambrian rocks have been available in temporary excavations. It is surely significant that in every case but one, the geologists who actually examined the exposures described them as fault junctions, or as something unambiguously fault-like. In this context, one can quote, for example, Groom (1899, p. 145), Symonds and Lambert (1861, pp. 155 and 157), and Robertson (1926, p. 167). These accounts combine with the present Gullet exposures to provide a uniform picture of a somewhat undulating plane of junction, vertical or dipping steeply to the east, against which the Silurian stratification is turned sharply upwards. (Only the occurrence on the west slope of the Worcestershire Beacon, originally described by Phillips $(1848$, pp. $34,59,65$, and $67-69)$, is not so clearly diagnosed, and the junction he portrayed might be interpreted equally as faulted or stratigraphical.) Fourthly, there is the prominent manner in which the western margin of the Malvernian cuts discordantly across the strike of the Lower Palaeozoic in a number of places. This apparent truncation of the Lower Palaeozoics by older rocks (which can only be explained here, either by faulting, or by invoking much more complex tectonics) is well shown by Phillips (ibid., p. 60 and pl. 1) and by Groom (1899, pl. 13). These various circumstances, individually and in combination, are explained most economically in terms of faulting; and I submit that, pending conclusive evidence to the contrary, they demand provisional acceptance of an important and virtually continuous fault boundary at the western margin of the Malvern chain.

\title{
REFERENCES
}

Blyth, F. G. H., 1952. Malvern Tectonics-A Contribution. Geol. Mag., 89, 185-194.

FaLCON, N. L., 1947. Major Clues in the Tectonic History of the Malverns. Geol Mag., 84, 229-240.

Groom, T. T., 1899. The Geological Structure of the Southern Malverns, and of the Adjacent District to the West. Quart. geol. Soc. Lond., 55, $129-169$.

PHILliPs, J., 1848. The Malvern Hills, compared with the Palaeozoic Districts of Abberly, Woolhope, May Hill, Tortworth, and Usk. Mem. geol. Sur., U.K., ii, part 1.

Raw, F, 1952. Structure and Origin of the Malvern Hills. Proc. Geol. Ass., Lond., 63, 227-239.

Reading, H. G., and A. B. Poole, 1961. A Llandovery Shoreline from the South Malverns. Geol. Mag., 98, 295-300.

Robertson, T., 1926. The Section of the New Railway Tunnel through the Malvern Hills at Colwall. Summ. Progr. for 1925, Mem. geol. Surv., U.K., 162-173.

Symonds, W. S., and A. LamberT, 1861. On the Sections of the Malvern and Ledbury Tunnels (Worcester and Hereford Railway) and the intervening Line of Railroad. Quart. geol. Soc., Lond., 17, 152-160.

\author{
Hatfield College, \\ DURHAM, \\ 21st May, 1962.
}

T. WHITWORTH.

SIR,-We had not anticipated that our paper would be controversial and feel that certain aspects need clarifying. Dr. Whitworth questions first the nature of the Malvernian/Silurian junction described by us in the Gullet Quarry, and secondly our interpretation of the western margin of the Malvern range. He does not comment on our conclusion that there was considerable 
erosion of earlier strata along the line of the Malverns before deposition of the Upper Llandovery.

The exposure of the junction in the Gullet Quarry which was visited by many geologists while it was visible in 1960 and 1961 has been destroyed. Originally the junction was mainly exposed in cross section. At present (June, 1962) the Malvernian, with a thin covering of Llandovery, makes a dip slope face which one can examine easily from the west. The face is about 5 yards high and runs over 50 yards in a north-south direction. The bulk of the strata exposed on this face is Llandovery sandstone, siltstone, shale, and clay with some shelly bands. But since the junction is very irregular the face is in places composed of Malvernian and a little excavation into the Llandovery can easily expose the contact. Hence one has 250 square yards of contact plane available for examination. The junction dips steeply to the west, but is seldom vertical and never overturned, except where undulations in the junction plane make it appear so. At one point hill creep has overturned the Llandovery, but in general the dip of both junction and Llandovery is about $60^{\circ}$, shallowing away from the junction.

We believe that the present exposure adds strength to our previous conclusions. Several knobs of Malvernian, with smoothly rounded weathered tops stick up and are surrounded by Llandovery. The edges of the knobs are bounded by joint or fault planes in the Malvernian, planes which do not continue into the Llandovery. The knobs are evidently sea shore stacks which were eroded along planes of weakness in Llandoverian times. Many boulders of Malvernian are visible, all are well rounded and some are embedded in a matrix of brachiopods and corals which are completely undistorted and often unbroken. They could not represent a fault breccia. Where boulders are absent at the junction finer grained sediments can be seen to be regularly stratified upon Malvernian.

Locally there is shearing at the contact. The amount however is very small; no more than one would expect where a crystalline formation underlying incompetent sediments is tilted almost to the vertical.

At the present day the only other outcrop of a Malvernian to Lower Palaeozoic junction in the Malverns is at the "sycamore tree exposure", south-east of West Malvern (SO764459), 5 miles north of the Gullet Quarry. Dr. Whitworth does not comment on this exposure, but it clearly indicates a basal conglomerate of Upper Llandovery in stratigraphical contact with the Malvernian.

In our view the most reasonable interpretation of both exposures is as unconformities. Indeed it is almost impossible to explain the existence of large boulders of Malvernian within the Llandovery unless some Malvernian was close to, or above sea level at this time. If the existence of a positive area in the Malverns during early Llandoverian times be admitted then the relationships we describe are the natural consequence of its gradual submergence towards the end of the Llandoverian.

It is beside the point to cite the numerous localities on the west side of the Malverns where the contact is faulted. We agree that this is commonly the case. If an unconformity can be demonstrated at only one locality (we suggest two) our stratigraphic argument is established.

The magnitude of the western faults remains in question. In the past it has been rather uncritically accepted that wherever Silurian is mapped against Malvernian a fault exists and that the throw of this fault is considerable because the whole of the Cambrian succession is cut out. For example Raw (1952, p. 228) says "the boundaries of the Malvernian, east and west, ... are now, perhaps universally, regarded as faults ", and his section (p. 232) shows a throw of 4,000 feet along this western fault.

We would like to reiterate the point made in our paper that these two exposures show that there is no prima facie case for invariably placing a major fault between Llandovery and Malvernian. We cannot say whether there is a continuous fault on the western side of the Malverns or not, but if there is, then at some localities it must lie either within the Malvernian or 
within the Llandovery; if within the latter then the throw must be less than 1,000 feet. It is unlikely to be a considerable fault and certainly is not everywhere a boundary fault.

\section{REFERENCE}

Raw, F., 1952. Structure and Origin of the Malvern Hills. Proc. Geol. Ass., Lond., 63, 227-239.

Department of Geology and Mineralogy,

H. G. READING,

UNIVERSITY MUSEUM,

OXFORD.

30th June, 1962.

\section{TORRIDONIAN MICROFOSSILS}

SIR,-In a recent publication, Naumova and Pavlovsky (Doklady Academy of Science, U.S.S.R., Vol. 141, No. 1, 1961) report the discovery of microfossils from Lower Torridonian rocks. As the locality from which the specimens came is not recorded in that paper, it might be as well to state that the specimens were collected from the village of Brochel, Isle of Raasay. The material in question was collected in 1957, after Professor Pavlovsky had suggested, during an excursion in Scotland, that the Torridonian might date from the same period of late-Pre-Cambrian time as the Riphean, which had proved to be fossiliferous.

DePartMent OF GEOLOGY,

ImPerial College of SCIENCE,

J. Sutton. LONDON, S.W. 7.

I4th June, 1962. 